Meta

Journal des traducteurs

Translators' Journal

\title{
Domestication and Foreignization in Translating American Prose for Slovenian Children
}

\section{Darja Mazi-Leskovar}

Volume 48, numéro 1-2, mai 2003

Traduction pour les enfants

Translation for children

URI : https://id.erudit.org/iderudit/006972ar

DOI : https://doi.org/10.7202/006972ar

Aller au sommaire du numéro

Éditeur(s)

Les Presses de l'Université de Montréal

ISSN

0026-0452 (imprimé)

1492-1421 (numérique)

Découvrir la revue

Citer cet article

Mazi-Leskovar, D. (2003). Domestication and Foreignization in Translating American Prose for Slovenian Children. Meta, 48(1-2), 250-265.

https://doi.org/10.7202/006972ar
Résumé de l'article

L'article décrit et analyse des exemples de domestication et de transformations étrangères de traductions de prose américaine destinées à des enfants slovéniens. Parmi les livres américains, La case de l'oncle Tom a la tradition la plus longue. Les traductions du roman sont présentées sous les aspects des efforts de domestication et de transformations étrangères. Pour compléter la description, quelques travaux additionnels publiés à différents moments de l'histoire de la traduction slovénienne sont brièvement discutés.
Ce document est protégé par la loi sur le droit d'auteur. L'utilisation des services d'Érudit (y compris la reproduction) est assujettie à sa politique d'utilisation que vous pouvez consulter en ligne.

https://apropos.erudit.org/fr/usagers/politique-dutilisation/ 


\title{
Domestication and Foreignization in Translating American Prose for Slovenian Children
}

\author{
DARJA MAZI-LESKOVAR \\ University of Maribor, Maribor, Slovenia \\ darja.leskovar@uni-mb.si
}

\begin{abstract}
RÉSUMÉ
L'article décrit et analyse des exemples de domestication et de transformations étrangères de traductions de prose américaine destinées à des enfants slovéniens. Parmi les livres américains, La case de l'oncle Tom a la tradition la plus longue. Les traductions du roman sont présentées sous les aspects des efforts de domestication et de transformations étrangères. Pour compléter la description, quelques travaux additionnels publiés à différents moments de l'histoire de la traduction slovénienne sont brièvement discutés.
\end{abstract}

\begin{abstract}
The purpose of this article is to describe and explore the examples of domestication and foreignization in translations of American prose read by Slovenian children. A few of the earlier American books that have entered the children's literature canon have been read by dual audience and among these Uncle Tom's Cabin has the longest tradition. The translations of the novel are presented in the light of domestication and foreignization endeavours. In order to complete and expand the picture of translating for children, a few additional works published in different eras of Slovenian translation history are briefly discussed.
\end{abstract}

MOTS-CLÉS/KEYWORDS

Slovenian/American children's literature, domestication, foreignization, balance

\section{Introduction}

This paper is based on my MA thesis where I researched American prose translated into Slovenian which used to be or is still read by Slovenian children. The research included only works that are either ranked among quality literature, according to American literary criticism, or have a special role in the history of the source literature. The period covered extended from the first translations in the middle of the 19th century to those issued in 1991, when Slovenia was declared an independent, democratic state. Here I am using the term 'children' in its largest sense, denoting persons who have not, according to general social consensus, reached the age of adulthood. To avoid ambiguity, however, the term 'children's literature,' will not be used indiscriminately. I agree with Riitta Oittinen's view expressed in her book Translating for Children $(2000)^{1}$ that it may be even more appropriate to speak about 'books for children' or 'books read by children' because even the implied source audience does not always correspond to the actual one, not to mention the non-implied audience, the actual readers of translated books that pass from culture to culture. ${ }^{2}$

American books that have enriched the choice of prose offered to Slovenian underage audience were most often written for American children. Still, among the translations, there are also works which have originally been intended for adult 
audiences. With the passing of time, they have most often been adopted by the underage readers of both the source and target literatures. Translations also include texts that are or used to be shared by the dual audiences of grown-ups and children. The research of a historical overview of translations from American English into Slovenian confirms that the boundary between children's and adult literature has been rather blurred from the first moment it was drawn. ${ }^{3}$ Moreover, a few of these earlier texts have entered the Slovenian children's literature canon, thus confirming Sandra L. Beckett's views in the book Transcending Boundaries about the present status of some earlier classics which were originally read by dual audience. ${ }^{4}$

The Slovenian children's book has always been closely linked with translation. Nowadays, when it is claimed that the gaining of independence and full sovereignty has brought new incentives and blossoming to cultural institutions, the long tradition of translating books for children continues and is respected. For example, in the year 2001, $172(63 \%)$ of the total 271 fiction books published for non-adult readers were translations. ${ }^{5}$ It is due to geographic and historic reasons that translating literature established itself so strongly. Surrounded by nations that all belong to different linguistic groups, Slovenes accepted translation and interpreting as a fact of life. Besides, they had to experience foreign rule for centuries. The western part of the territory was governed by the Italians, the eastern regions by the Hungarians, and the majority of the country by the German-speaking northern neighbours, the Austrians. Exposure to foreign cultures was thus unavoidable and it has resulted in a distinctive blend of national cultures and characters. Moreover, it has strengthened the position of the Slovenian language. Slovenian has become central to national identity, which is in line with the name of the nation itself: Slovenci, means "the people of the word." No matter what linguistic branch the rulers belonged to, Slovenian has always been spoken within the national territory and the written language has developed within the European tradition. For example, the Slovenian Bible first appeared in 1584, making Slovenian the twelfth language to receive a translation of the Bible. James Gow and Cathie Carmichael, the authors of Slovenia and the Slovenes, compare the role of the translation to that of the later English translation, "as it raised the quality of the written language rather as the King James Bible elevated the English of the early seventeenth century."7

However, translation established itself also in other spheres of literary creation. On the one hand, it was promoted by the fruitful development of Slovenian literature, on the other hand, by the general everyday "relationships with the more dominant cultures of Vienna and the Adriatic/which/ were complex and not simply ones of dominant versus stubbornly independent." 8 The multilingual surrounding being so vivid, translation was viewed as an obvious necessity.

In the 19th century, when the importance of books for children grew steadily among Slovenian educators, children were offered translations of books originally written in German. Hence, children's literature coming from the German-speaking source cultures exerted a strong influence on the development of the national literature for children in Slovenian. ${ }^{9}$ Taking into account that literatures "have all developed, at least in part, with the aid of literary exchange," as Jose Lambert has shown in the Routledge Encyclopedia of Translation Studies, this is in no way a particular situation. ${ }^{10}$ However, the positive attitude towards translations from the German language, mainly adopted during the Habsburg Empire, was most naturally extended to translations 
from other languages. Thus, long before the reading of books from different cultures was recognised as a means towards a culture of peace, tolerance and understanding, the Slovenian children's book market testified its openness for books travelling across national and linguistic borders.

However, the mere availability of fictional works from various source literatures tells too little about the readings offered to the minor audiences in a particular country. The choice of books tells only something about the target language book market. It is by considering the interplay between the texts in the source language and their translations that the nature of the offer can be perceived. Accordingly, it is indicative not only of what was or is translated at a certain moment or period of time, but also why and how. ${ }^{11}$ Moreover, it is extremely important to trace the reasons why books were or are translated in a particular way.

After paving the way to translation of fiction for Slovenian children, I will now focus on the translations of a few American books, which can serve as instances of the interplay between original texts and their culture and translations and the cultures they represent. However, the issue of transference between languages and literatures in general, and of children's literature in particular, seems to be influenced not only by the linguistic, stylistic and aesthetic aspects and standards, but also by the social and even the pedagogical beliefs and constructions. As there are too many challenges to be tackled in one article, I will concentrate on a few aspects of foreignization and domestication which reveal certain facets of the transposition of books from one literary system into another. Even though the American-Slovenian example will unveil specific traits related to the unique historic and cultural development of Slovenian children's literature, I hope it will also display a number of general characteristics which can be traced in the transmission of books across national and cultural borders.

\section{SLOVENIAN CULTURAL CONTEXT AND VIEWPOINTS OF TRANSLATING AMERICAN PROSE}

Even if the Slovenian contacts with the United States of America were sparse up to the mid 19th century, the first book translated from English did not originate in the British Isles, which are geographically so much nearer to Slovenia, situated in Central Europe, at the crossroads of the Alps, the Adriatic Sea and the Panonian Plain. The first translation from English into Slovenian came from America, when Benjamin Franklin's Poor Richard's Almanac was translated into Slovenian in 1812. Nevertheless, the real encounter with the culture of the 'new continent,' especially with the culture of the American Indians, started about two decades later, with the books of the Slovenian missionary Friderik I. Baraga. ${ }^{12}$ His texts were widely read by adults and children alike. However, a genuine interest in America - "the promised land" arose in the mid-19th century, when the wave of immigration from Central Europe to the USA began to involve the Slovenian territories. In this very period, American literature entered the Slovenian book market.

The breakthrough of American literature was marked by Harriet Beecher-Stowe's Uncle Tom's Cabin or Negro Life in the Slave States of America in 1853. The American 19th century best-seller thus started an open-ended dialogue between American authors, Slovenian translators and target readers, a dialogue that has continued uninterrupted ever since. This quite long-lasting relation, however, has had its ups and 
downs related to various specific factors determining the translation policy in the Slovenian target culture, especially extraliterary factors, such as political ones.

In the period of 140 years, American prose has been transmitted to Slovenian audiences living in four different states. Slovenians have witnessed the Habsburg domination, the royal Yugoslavia, the post-World War II communist Yugoslavia, and, finally, in 1991, independence. Each of the socio-political frameworks created specific cultures that have brought distinctive traits also including importing foreign literatures into the Slovenian literary system. The term culture in this context refers to "the way of life and its manifestations that are peculiar to a community that uses a particular language as its means of expression," as defined by Newmark in A Textbook of Translation. ${ }^{13}$ Slovenians were subjected to relatively frequent alterations of culture - positive and negative - which have naturally led to certain changes of cultural values and cultural expectations. These can be described as a constant demand for novelty which, together with the drastic evolution of the child image, above all in the 20th century, gave rise to a whole new set of factors affecting the transference of texts from various literatures into the Slovenian culture.

Importing of American fiction concerned various genres, from picture books to young adult novels, and various authors, most of whom considered classics of American literature but a few shared with the British or Canadian literatures. The Slovenian translations of American texts are manifold also from the viewpoint of the translation process applied when transmitting originals into Slovenian language. The books consist of literary texts and adaptations of various types.

I am aware that concepts related to translation are far from being universal and that the distinction between the terms translation and its "related concepts such as adaptation and rewriting" 14 are blurred and treated differently in various literary traditions. The term translation is found to be somewhere between translation and rewriting and is often regarded in its traditional sense as abridgement. However, the borderlines between the three categories are repeatedly being questioned, which is why I will use the term translation for any rendering of a text into another language, with the purpose of enabling the reader to grasp the text. ${ }^{15}$ In accordance with such a view the term adaptation obtains a status free from negative connotations: it is considered as an essential part of translation. The statement "all translation involves adaptation"16 thus opens the way to discussion about when adaptation is necessary or desired and what are the standards according to which the original and the targettext readers are shown the necessary respect. A fair approach to both the author and the recipient is an essential prerequisite of any translation. The original has been chosen for translation because of what it is and what it represents, and the reader is willing to devote a span of her/his lifetime to the reading of this particular literary work. Accordingly, my aim is, on the one hand, to view the extent to which American fiction translated for Slovenian children reflects such fairness.

On the other hand, I will observe the degree to which the originals have gained in the Slovenian translation. First, according to reader-response theory and intertextual studies, both of which have undermined the absolute authority of the original text, since the expansion of meaning of the original is a reality based on the very nature of reading, reception, and human perception. For the study of translations, the contribution of the reader-response methods is significant because they highlight the input of any reader during the act of reading and consequently recognize that multiple 
interpretations are legitimate and endow the text with a new meaning. ${ }^{17}$ Second, intertextual studies bring to the understanding of translation the recognition that "no artistic texts can be produced without an intertextual confrontation." 18 The dynamics of the interrelationship between the actual text and the texts already read determines the meaning of any translation. It opens new perspectives on viewing the text, especially in the case of texts that have been translated several times or offered to the readers in various versions.

This article will therefore explore adaptations of American texts entering the Slovenian literature. I will take a closer look at domestication, the ways by which the translators have tried to render the texts more easily accessible to Slovenian readers, and at foreignization whereby the translator retains the strangeness or foreignness of the source language text, and thus opts for the alterity. ${ }^{19}$

\section{THE RECEPTION OF AMERICAN PROSE IN SLOVENIAN TRANSLATIONS}

The translation of Uncle Tom's Cabin or Negro Life in the Slave States of America can be considered a significant point in the history of translations of American prose into Slovenian for at least three reasons. First, because as already mentioned, it paved the way for American literature into the Slovenian cultural sphere by answering the 'Zeitgeist,' the expectations of the target audience at a given historical moment. It was the time of the first wave of immigration into America when even people planning to sail to the new, 'promised land,' have been, as a rule, poorly informed about the country, they desired to enter into, not to mention the potential readers who would not even dream about leaving their home. However, the curiosity triggered by Baraga's writings was to be met with new information about the vast country where one could become rich without having any contact with native Americans. Second, because the novel was translated as early as 1853 , only a year after the first publication of the original in the USA, by two translators and published by two publishers in two different Slovenian cultural centres. Third, because the book has turned out to be one of the American texts that have been most often translated, issued and reprinted in Slovenian. The comparison of its translations can thus illustrate some of the aspects of domestication and foreignization applied to the translation of books, not only American ones, into Slovenian.

The technical terms foreignization and domestication are used according to the established literary terminology denoting the methods applied by translators when transposing a text from one language into another. ${ }^{20}$ Foreignization denoting in this context the conservation of significant amount of what is alien and unusual in the reading context of the new target audience but common, unique, distinctive or typical for the source culture. The foreign, strange or even the exotic retained in the text is expected to be a stimulus to reading. Domestication, on the other hand, is a strategy of translation which intervenes when the foreign and the odd is considered to represent a hindrance or barrier to the understanding of the text. However, even if there were no conscious decision for domestication, there is a certain degree of it in every translation because of the differences between the languages of the source and the target text. Domestication refers to all changes performed on various levels of the text in order to enable the target readers, the members of another nation, living in 
another geographical reality, with a specific socio-historical experience and a unique cultural background to fully grasp the text. It is thus a very powerful means of "bringing the translation closer to the target-language readers by speaking a familiar language." ${ }^{21}$ It is expected that the proper blend of foreignization and domestication is the answer to the requirements of the target readers.

How did the first translators of Uncle Tom's Cabin or Negro Life in the Slave States of America manage to fulfil this demanding task?

Even though both, Janez Božič and Franc Malavašič, used the German translation as their point of departure, their versions differ in many respects. This mere fact proves the reliability of the reader-response theory and of the intertextual approach. The two men were contemporaries, sharing the same semiotic space characterized by a racially homogeneous population where slavery was a completely unknown issue and where the questions related to national adherence have only started to manifest themselves. The so-called 'springtime of nations' (1848), demanding the rights related to national identity, has awakened the Slovenian intellectuals but without exerting greater impact on the viewpoints of the majority of the population. Hence, Slovenes remained loyal to the Habsburg crown, and the respect of authority and existing laws continued to be a part of everyday behavioural practice. On the other hand, Christianity with its teaching about brotherhood between people had a strong impact on the Slovenian national character. The two translators, both of Slovenian origin, were familiar with these specific traits of their contemporaries, and yet the books they offered to this same audience were not the same. The differences already appear on the title pages. Božič entitled the book Stric Tomaž aliživljenje zamorcov v Ameriki (od Henrijete Stowe) which would read in English Uncle Tomaž or Negro Life in America (by Henrijeta Stowe); Franc Malavašič entitled his translation Stric Tomova koča, ali življenje zamorcov v robnih državah severne Amerike which would read in English Uncle Tom's Cabin or Negro Life in the Slave States of North America.

Božič applied the principle of domestication by shortening the title and renaming the hero. He deleted any information that may have seemed to be too detailed for an average reader, unfamiliar with the political picture of North America, and replaced the name Tom by its Slovenian variant, Tomaž. The latter created a sense of familiarity and helped the Slovenian readers to enter the book. The zone of mutual understanding between the source-text readers and the translation/target-text readers has thus diminished the completely foreignizing effect of the title. ${ }^{22}$ Moreover, Božič Slovenized the spelling of the author's first name and used it according to the rules of Slovenian grammar. This adaptation enabled the target readers to learn that the author is a woman and thus contributed to the identification of the work in the Slovenian cultural sphere. Malavašič, on the other hand, changed the original title only by adding the adjective preceding America. The introduction of the word 'North' gives additional precision to the location, supposed to be strange to an average Slovenian reader. This form of addition reveals the translator's wish to compensate for the information about the geographical coordinates, self-evident in the semiotic space of the source-text readers.

However, most of the endeavour to satisfy the need for domestication is revealed in the prefaces with which the two translators start the books. Malavašič begins by underpinning the importance of the book by informing the readers that it has been 
translated into almost all the languages of the civilised nations. Afterwards, in order to help the reader understand the novel, he explains the signs absent in the Slovenian semiotic space. The ones related to racial characteristics are explained with the precision necessary for the understanding of the treatment of slaves and non-whites. $\mathrm{He}$ also explains the background of the title of the 'United States of America' and the geographical expression 'North-American.' Moreover, he gives information about the American currency. He thus brings his reader into touch with the American reality. The second part of the preface is also an example of domestication: Malavašič links the issue of slavery to the issue of treatment of servants. He points out that even in the States where slavery was permitted by legislation there were masters who treated their slaves better than some Slovenes dealt with their domestic servants. By drawing a parallel between the two treatments, he induces the readers to consider the fairness of treatment of the underprivileged, of those economically weaker and less respected in their social environment.

The second translator, Janez Božič, also introduces his text to the reader with the information about the importance of Uncle Tom's Cabin, mentioning that it has already been translated into some other Slavic languages. His aim to adapt the text and cater to the needs of his readers, is revealed in the localizing of the story. The three American states where the story takes place are introduced with basic geographic data.

In order to make the readers prepared for reading about an issue completely strange to Slovenian culture, Božič also presents the condemnation of slavery that Beecher-Stowe expressed in the 45th chapter / Concluding Remarks / of the novel. Additionally, he also introduces the specific socio-cultural signs related to racism and thus contributes to the comprehensibility of the book. By drawing parallels between the American culture and the Slovenian culture, he prepares the target reader to experience something similar to what the source-language reader has experienced. He explains that even though the institution of slavery is unknown among Slovenians, suffering caused by immoral and unfair behaviour is not. It is frequently hidden behind the walls of the families, and often rooted in alcoholism, an evil that should be eradicated by joint efforts, not left to be fought with by the Church alone. In this context the importance of teaching people responsibility is underlined. Responsibility should be assumed also for the treatment of domestic servants. Pointing to the clandestine existence of unjust behaviour, the translator encourages the readers to combat injustice and show compassion for their fellow citizens. Another sign of the effort to bring the story closer to the readers is a suggestion for those who would like to help in the American cause: they should assist the Slovene missionaries in the USA.

The two Introductions thus display a strong effort to domesticate the fundamental issues of the book. By expressing their individual view of the target society they succeed in demonstrating that the otherness and strangeness of the topic and theme can easily be related to the domestic situation familiar to Slovenians. In this way they bring an extension to the meaning conveyed by the original to Slovenian target readers. Besides, by presenting the importance and the popularity of the novel on the international level, they give the work a special status in the target cultural sphere and thus pave the way for its successful domestication. In addition to these steps towards domestication, they also contain an important element of foreignization: the introduction of the issue of slavery and related themes and of America as a country with its own problems. 
Analysis of the texts shows that both translators shortened and summarised many chapters of the book, especially those containing less action. For example, Božič gives the main information from the first three chapters of the original in his first chapter. The same procedure can be noticed in the rest of the translation. Consequently, some lines of the action are presented in a new order. A few episodes of the subplot that are narrated in various chapters in the original are thus considerably shortened and condensed in a single chapter. In spite of this procedure the translators managed to preserve the two parallel stories (the one about Uncle Tom and the other about the young Negro family) and the spirit of the novel.

The two translations differ also in the individual translation of proper names. However, they are both inconsistent in the usage of original names and their domesticated forms. Some names, like that of Mr. Bird, keep their original forms, which is a sign of foreignization, while the Slovenization of other names reveals domesticating goals, resulting in different spellings in the two versions.

A third translation of Uncle Tom's Cabin was issued in 1918. The translator Silvester Košutnik formed a new title: Stric Tomova koča: Povest iz suženjskega življenja/Uncle Tom's Cabin: A Story about Negro Life followed by a note "Translated from the German original." The book is shorter than the 1853 versions, and domestication is revealed in the Slovenization of proper names: for example, George Harris has become Ivan Harij.

In 1934 the most important Slovenian translation of the novel was published. Its significance is not due just to the new title, Koča strica Toma/Uncle Tom's Cabin, which became the standard, but to the translated text as a whole: it reveals a new approach towards translation, and consequently towards domestication and foreignization.

The cover page itself is a turning point as the author's name is written correctly in its complete form. For the first time, as well, the information about the adaptation is given on the cover page. The translator Olga Grahor has also written the preface and the notes. In the former she gives the biography of Harriet Elisabeth BeecherStowe, enabling the target audience to get to know the author. The reference section called A Key to Uncle Tom's Cabin (1853), provides additional tools to understanding the background struggle that had to be fought by the writer after the publication of her book.

As to domestication and foreignization strategies, the detailed and complex account of the geographical, socio-historic and general cultural aspects leading to slavery is most important. The target readers are thus informed about the institutions and points of reference, such as Anti-Slavery Society, John Brown's rebellion and the Fugitive Slave Act. In this way foreignizating elements are presented as facts that the reader should be familiar with in order to understand the novel. Also H. BeecherStowe's preface to the European translations is introduced as another source of insight into American cultural space. The book closes with the reference section Notes, giving additional specification of a few culturally bound terms, presumably unknown to average Slovenian readers, and the translator's commentary on the usage of proper names. The names are not only spelled in the original form, but also presented with a phonemic transcript. The unique exception is the name 'America,' which was by then already familiar to Slovenes as 'Amerika.' Such a degree of foreignization clearly indicates that English was no longer completely unknown to the Slovenians. 
A specific feature of this translation is the summarising of the untranslated parts in smaller print at the beginning of each chapter. For example, the introductory text to Chapter 2 sums up most of the events of the original Chapters 3, 5, and 6 and even part of Chapter 7. The part of Chapter 19, in which St.Clare reveals to Ophelia what he thinks and feels about slavery and about the capitalist exploitation in England, forms Chapter 6 of the translation. Hence, in spite of the domestication which is revealed in the selection of the parts that are most evocative for the target audience, the message of the novel keeps its central position in the Slovenian book. However, this is not a surprise, since the translator has called attention to it in her introductory effort to bring the issue of the novel within easy grasp of the target readers. Her foreignization and domestication strategies are thus supported with the structure of the text. This book became the basic text for all subsequent editions of Uncle Tom's Cabin in the Slovenian language.

After the second world war Uncle Tom's Cabin was first republished in 1954. The same translator Olga Grahor wrote the introduction "For the new edition of Uncle Tom's Cabin" in which she introduced the slavery issue, the author and her books for young readers. She explains that colonialists imported slaves to perform the hardest labour and that slaves had no rights whatsoever and that even their children became the sole property of their masters. It is stressed that Beecher-Stowe wrote the novel in order to protest against the enacted law prohibiting any assistance to the fugitive slaves. The writer is presented as a happy wife and mother who could not stand the idea that other wives should be separated from their husbands and children. The introduction with pronounced child reader semiotic signs indicates a clear shift in the target audience.

The preceding Slovenian translations of Uncle Tom's Cabin, a book primarily written for adults, did not address children but the 1954 adaptation did. Contrary to the first post second war edition, the earlier editions may have been addressing double audiences, adults and minors. First, because the recognition of the existence of "shifting borders between children's and adult literature" ${ }^{23}$ admits the possibility of ranking the book among those initially read by adults and in the course of time also by teenagers. Second, because the age when an individual reader actually starts reading adult literature varies a great deal and does not always coincide with the generally agreed age demarcations separating the two literatures. However, even though the 1954 text of the book Koča strica Toma might have addressed double audiences, the classification of the book depends to a large extend on its visual presentation, the book cover, illustrations and the accompanying texts. The 1954 book jacket and the illustrations call for a child reader. Besides, the introduction with its foregrounding of the images of children, of the mother and family, of home and shelter, all belonging to the child reader's semiotic space, reveal the orientation towards a precisely targeted public. ${ }^{24}$ This audience has undoubtedly been secured as the book was made one of the elementary school canon books. ${ }^{25}$

Thus, it is the young teenager audience that the translator is addressing when informing that the book is a sentimental novel even if based on real facts. She particularly strongly underlines that $\mathrm{H}$. Beecher-Stowe was not ignorant about the oppression of the working class in Europe, and that she even predicted a social revolution. A specific type of domestication can be discovered here: "domestication for political 
ideas" 26 that will be furthermore unveiled in the editor's foreword and drastically exposed in the text itself.

The introduction is followed by the foreword of the editor who adapted the novel. While stating that the original text had to be shortened and adapted, she emphasises that despite the adaptation "the whole story and the way of narration, and above all the basic idea and the intention of the writer are preserved." ${ }^{27}$ The comparison with the original and with the 1934 issue, however, reveals the opposite. It is evident that all the sections of the text where $\mathrm{H}$. Beecher-Stowe claims that Christianity and slavery cannot exist together have been deleted. The domestication conditioned by the communist regime changes the message of the novel and completely distorts the author's argument and consequently the spirit of the book. Here I give a few examples to illustrate my point.

On page 38 of the Slovenian version the senator's wife tells her husband, "You know, John, that I don't know anything about politics, but I know that I must feed the hungry, clothe the naked, and comfort the desolate." Beecher-Stowe, on the contrary, wrote, "Now, John, I don't know anything about politics, but I can read my Bible; and there I see that I must feed the hungry, clothe the naked, and comfort the desolate; and that Bible I mean to follow." (77). There is another big discrepancy between the original Chapter 28 entitled "Reunion" and Chapter 19 conveying its content in the Slovene version. Even if both chapters have the same title, the Slovenian text does not adequately convey the message of the original. Several key elements are left out, even the mention of Mozart's Requiem and Dies Irae. The two musical references are too obviously related to the Christian view of life and death: the former, indicating a composition played at the occasions when remembering the dead, with the title derived from the start of the Christian prayer for the dead "Requiem aeterna dona eis" (Eternal rest grant unto them); the latter composition, entitled with the words starting one of the mediaeval hymns sung at the Mass for the dead (Day of wrath! O day of mourning). The context related to the musical titles is linked to the topic that had to be avoided by the then educators and teachers, hence the musical references had to be deleted as well. The sequel of the story, indicating that the dying man is reunited with his mother is, consequently, also omitted. Hence, the message of the title and of the conclusion of this chapter are not within the reach of the Slovenian reader. The adaptation thus proves that the domestication was in line with the political regime that required the indoctrination of young readers and would not let literary works convey messages they deemed inappropriate.

Several reprints of the 1954 edition followed and today's schoolchildren read the same distorted text as their counterparts almost fifty years ago. The fictional presentation of the anti-slavery movement still does not correspond either to the historical truth or to Beecher-Stowe's intention that gave initial impetus to the writing of the book.

While the case study of Uncle Tom's Cabin is typical for the history of Slovenian translations, it lags behind the current endeavours reflecting the democratic changes in Slovenia, present also in the field of translation. It is not just the translations from other languages, as for instance the newest translation of the Swiss German Heidi by Johanna Spyri, that are edited without the domestication resulting in 'literary ideological cleansing.' Slovenian children have already been offered translations of American classics that are a sufficient proof of the fair domestication, revealing respect for the 
original, the author and the reader. To illustrate the positive development in Slovenian translation policy, I am going to refer briefly only to a few prose works which complete the presentation of the interplay between domestication and foreignization revealed by the translations of Uncle Tom's Cabin.

Among the first translations in the post-second war period where domestication does not mutilate the content and the idea of the book is the 1974 edition of Ben-Hur (Lewis Wallace). The text, edited for the dual audience like all previous translation, expands the number of references the author annotated for the American readers. Hence, the novel has become more accessible for the target readers living in another country, in another period of history and in secularized society. Another type of domestication effort is revealed in the translations of The Leatherstocking Tales (J.F.Cooper), a series of books that has been accompanying Slovenian readers from the start of the 20th century. Even though the books have been introduced to the target market with the cover notice "Tales for young people," which proves to be the translator's domesticating stroke in order to attract the target reading public, the books were addressing the adult and younger readers. Various editions display all the above foreignization strategies, spurred by the very content of the books, the setting, and the protagonists. On the other hand, the translations of Mark Twain's The Adventures of Tom Sawyer and The Adventures of Huckleberry Finn, exemplify the passage from pronounced domestication, which, nonetheless, respected the content and the message of the original text, to equilibrium between foreignization and domestication. The latest editions, The Adventures of Tom Sawyer in 1960 and The Adventures of Huckleberry Finn (1962), thus supply entire texts with all the cultural references related to American history and geography that are unknown to the targeted elementary school readers.

Another Mark Twain book that can serve as an example of the development of the awareness of the importance of the interplay between domestication and foreignization is The Prince and the Pauper. The most recent translation of the "Tale for Young People of All Ages" includes not only the references needed for the Slovenian audience reading an American book based on English social history but also the translation of the 16th century English song. In order to conserve its role in the text, it is rendered in mediaeval Slovenian. However, the foreignization effect doubled by the temporal gap that required the usage of the old, today incomprehensible target language, is lessened in the reference section where the song is translated into contemporary Slovenian.

\section{CONCLUSION}

Slovenian translations of American prose present a range of efforts aiming at attaining the equilibrium between domestication and foreignization. The mere choice of books originating in another country and culture by itself speaks in favour of foreignization because "there is no point in translating books of a kind that merely add to a very large number we already produce" as stated by Adrian Chambers in his book Reading Talk. ${ }^{28}$ The appeal of otherness, of the alien and unfamiliar, is strongly felt in the choice of books till (at least) the mid-20th century, since the texts have introduced the realities of the world that are typically (or stereotypically) American, defining the traditional image of the United States of America. Foreignness and 
strangeness, the presentation of another place, time and culture have thus been regarded as positive qualities. On the other hand, the translations offer a wide range of domestication strategies, testifying that the awareness of the need of domestication was present throughout the history of the passage of American texts into Slovenian.

The early translations are domesticated first of all via abridgements in which action prevails over description or reflection and meditation. Additionally, the texts are preceded by an introduction either in the form of a preface or a foreword in which the cultural references, presumably unfamiliar to an average reader, are given and explained. Some translators even take a step further and relate the theme, seemingly entirely disconnected from the target-reader's semiotic space, to realities wellfamiliar to Slovenians. When this happens, the originals expand their meaning or even gain a new lease of life with a target audience. ${ }^{29}$ However, among the translations there are also numerous cases where meaning is restricted. Restrictions can be detected on various layers. In most instances the central message, the deeper meaning, is rendered in spite of the omissions of the textual material. As a rule, later translations are less and less abridged and the inner textual interplay of meaning and sense is increasingly conveyed.

A clear deviation from this natural disclosure of literary works in any target culture is the translations that were edited in the post second world war period. There a reversal is to be noticed: even the texts that had already entered the Slovenian cultural sphere in their integrity and complexity risked being reduced and impoverished. They were submitted to ideological reinterpretations and if inappropriate, they were domesticated anew. One of the strategies applied was the omission of all those sections that would disclose an undesired message. In the case of cultural signs that did not have a central role in the construction of meaning, the individual signs were either replaced with more neutral ones (Christmas is replaced by New Year) or simply omitted. Such domestications are a proof of a conscious neglect of the basic standards of translation as presented in the book Children's Literature Comes of Age by Maria Nikolajeva. In the chapter "Cultural Context and Translatability," the author claims that "translation of children's books requires not simply the transmission of meaning but the ability to arouse in the reader the same feelings, thoughts and associations experienced by readers of the source text." ${ }^{30}$ I suppose that these requirements are not limited to the translations of children's books only, and that their neglect is the sign of the misinterpretations of the right to domestication. The final results of such manipulation with the text can be considered as "further evidence of the interplay between translator, implied reader and changing cultural expectations." ${ }^{31}$ However, in the Slovenian context the adjective 'cultural' is to be considered in its broadest sense, and it could well be replaced by the word 'political.'

Domestication thus proves to be a strategy requiring ethical responsibility towards the reader and the author. The respect for the reader is expressed with the application of the correct balance between domestication and foreignization. The history of the translation of American prose into Slovenian testifies that the entrance of the semiotic signs alien to the Slovenian space was gradual and evolved with the general opening of the nation to the world. It enabled not only the encounters with the United States but also, at least indirectly, with Canada and Great Britain. With the former, for example, with translations of E.T. Seton and Jack London, with the latter, for instance, with Mark Twain's The Prince and the Pauper and the books of Frances 
Hodgson Burnett. Like every cultural exchange, the translation of American texts resulted in gains also outside the primary area it took place in and accordingly to reader response theory its positive repercussions are to be felt in the whole literary field.

Intertextuality gained in importance and what at the beginning of the cultural encounters between American prose and Slovenian readers seemed to be too specific of the source culture, gradually became a required and constituent part of the target language texts. Literary allusions, citations, prefaces that originally addressed the source readers have been incorporated into Slovenian translations. Even if such a shift was also due to social and historical changes that have brought countries and people of all the world together, it was likewise fostered by the gradual professionalization that has become an increasingly felt feature of the twentieth-century translation.

While the domestication in the earlier periods was limited to explaining culturally specific signs, more recent translations reveal care for the adequate choice of register and a commonsensical approach to the whole area of cultural categories. In the best translations the author's personal style is evidently the supreme authority of the translator. ${ }^{32}$ However, this authority serves both author and reader alike. ${ }^{33}$ The translator, being first and foremost a reader, is, because of her of his activity the reader par exellence who "aims to produce "what the author might have written had he been writing in English in the first place" as Ronald Jobe cites the English translator Anthea Bell in his article "Translation," published in Hunt's International Companion Encyclopedia of Children's Literature. ${ }^{34}$ Hence, masterpieces of translation of American books read as they might have read if their authors had been writing in Slovenian in the first place. Such a progress in the quality of translations inspires hope that "there will always be unique voices /authors/, translators who respect them /the differences/ and opportunities for retranslation of books that last beyond a generation." ${ }^{35}$ Besides, it also inspires hope that the differences and opportunities for translations will be considered in the view of Article 13 of the Convention on the Rights of the Child, which reads: "the child shall...receive and impart information and ideas of all kinds, regardless of frontiers, either orally, in writing or in print, in the form of art... of the child's choice." Consequently, it also gives rise to a wish that children in other countries may have the right to choose among translations of Slovenian books that, domesticated to the proper extent, can bring young readers the real pleasure of the text.

\section{NOTES}

1. Oittinen 2000: 62 .

2. See Oittinen, 2000.

3. See Beckett, 1999.

4. Ibid.

5. The figures are from the Slovenian Children's Library Research Centre.

6. Gow 2000: 11.

7. Gow 2000: 63 .

8. Gow 2000: 62.

9. See Brinar, 1905.

10. Lambert in Routledge Encyclopedia of Translation Studies, 1998: 131.

11. Oittinen, 2000: 74 . 
12. Friderik Irenej Baraga (1797-1886), Slovenian missionary, the first bishop of Michigan.

13. Newmark 1988: 94.

14. Lambert in Routledge Encyclopedia of Translation Studies, 1998: 130.

15. See Newmark 1991.

16. Oittinen, 2000:xiv.

17. See Guerin, 1999.

18. Nikolajeva 1996: 154.

19. Robinson in Routledge Encyclopedia of Translation Studies, 1998 pp. 126-7.

20. See Oittinen 2000.

21. Oittinen 2000: 84 .

22. Nikolajeva, 1996

23. Beckett 1999: xviii

24. Nikolajeva 1996: 27-34.

25. Elementary school in Slovenia: children from the age of 6 to 14 .

26. Oittinen 2000: 99.

27. Koča strica Toma, p. 6 .

28. Chambers 2001: 118. The quote evoking a present situation in England, can be applied to any time of Slovenian translation efforts, if the determinant 'very large', related to the quantity of domestic production, is omitted.

29. See Desmet, 2001.

30. Nikolajeva 1996: 28.

31. Lathey 2001: 111.

32. See Chambers 2001.

33. See Oittinen, 2000.

34. Ronald Jobe in Hunt's International Companion Encyclopedia of Children's Literature: 521.

35. Lathey “From World Republic to World Market: Emer O’Sullivan on Comparative Children's Literature,” Signal 95, May 2001: 111.

\section{REFERENCES}

\section{Primary sources:}

Cooper, J.F. (1989): The Last of the Mohicans. London: Bantam Books.

Cooper, J.F. (1980): The Deerslayer. New York: New American Library.

Cooper, J.F. (1992): The Prairie. New York: Oxford University Press.

Cooper, J.F. (1960): The Pathfinder. New York: Washington Square Press

Cooper, J.F. (1964): The Pioneers of the Sources of the Susquehanna. New York: A Signet Classic.

Cooper, J.F. (1900): Natanael Bumppo, Strelec. Ljubljana: Janez Giontini.

Cooper, J.F. (1900): Natanael Bumppo, Poslednji Mohikanec. Ljubljana: Janez Giontini.

Cooper, J.F. (1901): Natanael Bumppo, Naseljenci. Ljubljana: Janez Giontini.

Cooper, J.F. (1901): Natanael Bumppo, Stezosledec. Ljubljana: Janez Giontini.

Cooper, J.F. (1901): Natanael Bumppo, Na preriji. Ljubljana: Janez Giontini.

Cooper, J.F. (1926): Zadnji Mohikanec. Maribor: Tiskarna sv. Cirila.

Cooper, J.F. (1973): Naseljenci. Ljubljana: Mladinska knjiga.

Cooper, J.F. (1973): Divjačinar. Ljubljana: Mladinska knjiga.

Cooper, J.F. (1973): Stezosledec. Ljubljana: Mladinska knjiga.

Cooper, J.F. (1973): Zadnji Mohikanec. Ljubljana: Mladinska knjiga.

London, J. (1994): White Fang and The Call of the Wild. London: Penguin books.

London, J. (1927): Klic prirode. Celje: Brata Rode in Martinčič.

London, J. (1949): Beli očnjak. Ljubljana: Mladinska knjiga.

Seton, E. T. (1987): Animal Heroes. Lincoln and London: University of Nebraska Press.

Seton, E. T. (1926): Stari volkodlak. Golob Arno. Celje: Brata Rode in Marinčič.

SETON, E. T. (1950): Črni kljusač in druge povesti. Ljubljana: Mladinska knjiga.

Seton, E. T. (1911): Rolf in the Woods. London: Constable and Company Ltd.

SEton, E. T. (1938): Rolf Gozdovnik. Ljubljana: Sled. 
Stowe, H. B. (1981): Uncle Tom's Cabin. London: Bantam Books.

Stowe, H. B. (1853): Stric Tomova koča ali življenje zamorcov v robnih deržavah svobodne severne Amerike. Ljubljana: Janez Giontini.

Stowe, H. B. (1853): Stric Tomaž ali življenje zamorcov v Ameriki. Celovec: Janez Leon.

Stowe, H. B. (1932): Stric Tomova koča. Povest iz suženjskega življenja. Ljubljana: Anton Turk.

Stowe, H. B. (1934): Koča strica Toma. Ljubljana: Založba tiskarne Merkur.

STowe, H. B. (1954): Koča strica Toma ali življenje črncev v suženjskih državah Amerike. Ljubljana: Mladinska knjiga.

Sтоше, H. B. (1973): Koča strica Toma. Ljubljana: Mladinska knjiga.

Twain, M. (1993): The Adventures of Tom Sawyer. New York: Oxford University Press.

Twain, M. (1985): The Adventures of Huckleberry Finn. London: Penguin Books.

Twain, M. (1964): The Prince and the Pauper. London: Signet Classic.

Twain, M. (1921): Mali klatež Tom Sawyer. Ljubljana: Omladina.

Twain, M. (1947): Pustolovščine Toma Sawyerja. Ljubljana: Mladinska knjiga.

Twain, M. (1960): Prigode Toma Sawyerja. Ljubljana: Mladinska knjiga.

Twain, M. (1948): Pustolovščine Huckleberryja Finna. Ljubljana: Mladinska knjiga.

Twain, M. (1962): Prigode Huckleberryja Finna. Ljubljana: Mladinska knjiga.

Twain, M. (1910): Kraljevič in berač. Kranj: Lampre.

Twain, M. (1921): Kraljevič in berač. Ljubljana: Anton Turk.

Twain, M. (1953): Kraljevič in berač. Ljubljana: Mladinska knjiga.

Twain, M. (1982): Princ in beraček. Ljubljana: Mladinska knjiga.

Wallace, L. (1888): Ben-Hur a Tale of the Christ. Leipzig: Tauchnitz.

Wallace, L. (1899): Ben-Hur Roman iz časov Kristusovih. Gorica: Gori?ka tiskarna.

Wallace, L. (1931): Ben-Hur. Povest iz Kristusovih časov. Ljubljana: Jugoslovanska knjigarna.

Wallace, L. (1974): Ben-Hur. Povest iz Kristusovih časov. Celje: Mohorjeva družba.

\section{Secondary sources:}

BAKer, M., ed. (1998): Routledge Encyclopedia of Translation Studies. London and New York: Routledge.

Becкetт, S., ed. (1999): Transcending Boundaries Writing for a Dual Audience of Children and Adults. New York and London: Garland Publishing, Inc.

Brinar, J. (1905): "O slovstvu za mladino" (About Literature for Children) Pedagoški letopis. Ljubljana: Slovenska šolska matica.

Chambers, A. (2001): Reading Talk. Woodchester: Thimble Press.

Desmet, M.K.T. (2001): “Intertextuality/Intervisuality in Translation: The Jolly Postman's Intercultural Journey from Britain to the Netherlands," Children's Literature in Education, Vol. 32 No. 1: 31-43.

Gow, James and Cathie Carmichael (2000). Slovenia and the Slovenes. London: Hurst and Company.

Guerin, W. (1999): A Handbook of Critical Approaches to Literature. New York and Oxford: Oxford University Press.

Hunt, P., ed. (1996): International Companion Encyclopedia of Children's Literature. London and New York: Routledge.

JAMNIK, T. (2002): “Lani je izšlo 334 novih mladinskih knjig” (Last year 334 new children’s books were published).

Jobe, R. (1996): “Translation.” See Hunt, ed. International Companion Encyclopedia of Children's Literature, 519-529.

LAMbert, J. (1998): “Literary Translation, Research Issues.” See Beker, ed. Routledge Encyclopedia of Translation Studies, 130-133.

Lathey, G. (2001): “From World Republic to World Market: Emer O'Sullivan on Comparative Children's Literature” Signal 95: 105-111. 
Mazi-Leskovar, D. (1997): "Srednješolci in (ameriška) mladinska književnost/High school students and (American) children's literature" in Vestnik 31, No. 1-2: 22-26.

Newmark, P. (1988): A Textbook of Translation. New York and London: Prentice Hall.

Newmark, P. (1991): About Translation. Clevedon, Philadelphia, Adelaide: Multilingual Matters Ltd.

Nikolajeva, M. (1996): Children's Literature Comes of Age. Toward a New Aesthetic. New York and London: Garland Publishing, Inc.

Oittinen, R. (2000): Translating for Children. New York and London: Garland Publishing, Inc.

Robinson, D. (1998): “Literary Translation Practices." See Baker, ed. Routledge Encyclopedia of Translation Studies, 126-127. 